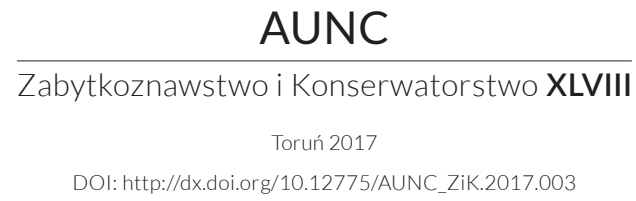

Przyczynki do dziejów nowożytnego budownictwa i kamieniarstwa w Gdańsku na podstawie historii budowy Spichrza Królewskiego (1606-1608)

tzw. Starej Apteki (1636-1638)

i Małej Zbrojowni (1643-1645)

\title{
FRANCISZEK SKIBIŃSKI
}

Zakład Historii Sztuki Średniowiecznej i Nowożytnej,

Wydział Sztuk Pięknych, UMK w Toruniu

e-mail:franek_skibinski@umk.pl

Key-words: Gdańsk, Small Armory, Old Farmacy, Royal Granary, architecture, building industry, stonecutting, building masters, Wilhelm Richter

Słowa kluczowe: Gdańsk, Mała Zbrojownia, Stara Apteka, Spichrz Królewski, architektura, budownictwo, kamieniarstwo, mistrzowie budowlani, Wilhelm Richter

\begin{abstract}
Notes on the early modern building and stonecutting industry in Gdańsk as illustrated by the building history of the Royal Granary (1606-1608), the so-called Old Farmacy (1636-1638), and the Small Armory (1643-1645)

Based on archive quarries, the article focuses on building history of several edifices created in Gdańsk in the first half of the seventeenth century. The group examined here includes the Royal Granary (1606-1608), the so-called Old Farmacy (1636-1638), in fact a munition storage, and the so-called Small Armory (1643-1645), all financed by the city. Conclusions drawn from the scrutiny of town bills offers detailed knowledge of the history of these edifices and, in more general terms, of the building practices in seventeenth century Gdańsk. The article also introduces several hitherto
\end{abstract}


unknown figures engaged by the city authorities to carry out public commissions, including the building master Reinhold de Clerck who worked at the Old Farmacy and the Small Armory, and the sculptor and stonecutter Herman Knut (Knust) who created masonry for the former. In addition to that, it provides new information about the sculptor Wilhelm Richter, a continuator of the Van den Blocke enterprise who played a pivotal role in Gdańsk in the middle of the seventeenth century. Responsible for creating the masonry and architectural detail for the Armory, he also worked at the Town Hall and the High Gate complex.

\begin{abstract}
Abstrakt
W niniejszym artykule, opartym na analizie źródeł pisanych, omówiono kilka budowli wzniesionych w Gdańsku w pierwszej połowie XVII wieku. Do grupy tej należą: Spichrz Królewski (1606-1608), tzw. Stara Apteka (1636-1638), będąca w rzeczywistości magazynem amunicyjnym, oraz tzw. Mała Zbrojownia (1643-1645). Inwestycje te były finansowane z kasy miejskiej. Analiza rachunków miejskich dostarcza nowej, szczegółowej wiedzy o historii ich budowy, a także, w szerszym kontekście, o przebiegu procesów budowlanych w siedemnastowiecznym Gdańsku. W artykule zaprezentowano też sylwetki kilku nieznanych dotąd postaci, takich jak mistrz budowlany Reinhold de Clerck, który wzniósł tzw. Starą Aptekę i Małą Zbrojownię, oraz rzeźbiarz i kamieniarz Herman Knut (Knust), który wykonał dekorację kamieniarską pierwszej z tych budowli. Podano w nim ponadto nowe informacje na temat rzeźbiarza Wilhelma Richtera, kontynuatora warsztatu założonego przez rodzinę Van den Blocke. Jako rzeźbiarz i kamieniarz odgrywał on wiodącą rolę w Gdańsku w połowie XVII wieku; był twórcą kamieniarskiego wystroju Małej Zbrojowni, pracował także w ratuszu i przy kompleksie Bramy Wyżynnej.
\end{abstract}

Gdańsk, największe miasto nowożytnej Rzeczpospolitej, był zarazem jednym z wiodących ośrodków w zakresie architektury i budownictwa. W ciągu XVI i XVII wieku wzniesiono tu liczne monumentalne budowle użyteczności publicznej o bogatej szacie architektonicznej oraz wiele innych godnych uwagi obiektów, głównie prywatnych kamienic. Dynamiczny ruch budowlany miał swoje źródła w gospodarczej koniunkturze, jaką w tym czasie cieszył się Gdańsk, przyciągając budowniczych z różnych krain Europy ${ }^{1}$. Oprócz wiodących architektów i inżynierów, cieszących się nieraz ponadregionalną sławą, nad Motławą działali też liczni inni mistrzowie i czeladnicy murarscy i kamieniarscy, cieśle, kowale, szklarze, malarze i reprezentanci innych zawodów,

1 Franciszek Skibiński, „Architekci, budowniczowie, kamieniarze i rzeźbiarze obcego pochodzenia w Gdańsku 1550-1630. Szkic z dziejów migracji artystycznej”, Biuletyn Historii Sztuki 77 (2015): 5-35. 
bez których niemożliwy byłby tak intensywny rozwój budownictwa, a którzy zazwyczaj pozostają dziś niemal anonimowi.

Mimo znaczenia tego ośrodka, wiedza o architekturze i budownictwie nowożytnego Gdańska pozostaje niepełna ${ }^{2}$. Historia wielu ważnych gdańskich obiektów nie została dotąd wystarczająco rozpoznana, podobnie jak organizacja procesu budowlanego oraz struktura lokalnego środowiska. Drugim obok badań zabytkowej substancji - co ze względu na zniszczenia wojenne, ale też wcześniejsze przekształcenia, jest szczególnie utrudnione - nurtem studiów nad dziejami gdańskich zabytków architektury musi być analiza źródeł pisanych, bogatych i stosunkowo dobrze zachowanych ${ }^{3}$. Wiedza czerpana z pisanych dokumentów, konfrontowana z innymi materiałami, zwłaszcza ikonograficznymi, i poparta oglądem, a najlepiej pełnymi badaniami architektonicznymi, jest niezbędna zarówno dla poznania historii architektury Gdańska, jak i dla lepszego zrozumienia procesu budowlanego. Wagę interdyscyplinarnego podejścia podkreślał ostatnio Marian Arszyński: „Dla każdego współczesnego badacza rolę wymownego źródła materialnego pełnić powinna przecież nie tylko zabytkowa budowla w swej finalnej formie. Ogromnie ważną wymowę posiadać mogą także udokumentowane źródłowo informacje charakteryzujące okoliczności towarzyszące jej powstaniu"4.

Wychodząc z tych założeń, w niniejszym artykule przedstawiam - opartą na analizie źródeł pisanych - historię budowy, finansowanej z kasy miejskiej, trzech gdańskich obiektów z pierwszej połowy XVII wieku. Najwcześniej, bo w latach 1606-1608 powstał Spichrz Królewski, następnie, w latach 1636-1638, tzw. Stara Apteka (w rzeczywistości prawdopodobnie magazyn

2 Zob. najbardziej znaczące opracowania na temat gdańskiej architektury i budownictwa XVI i XVII w.: Georg Cuny, Danzigs Kunst und Kultur im 16. und 17. Jahrhundert (Frankfurt am Main: Heinrich Keller Verlag 1910); Erich Keyser, Die Baugeschichte der Stadt Danzig, red. Ernst Bahr (Köln: Böhlau, 1972). Zob. też ważne popularyzatorskie opracowanie Jacek Friedrich, Gdańskie zabytki architektury do końca XVIII wieku (Gdańsk: Wydawnictwo UG, 1995).

3 Konieczność łączenia badań źródłowych i gruntownego rozpoznania substancji i struktury budynku jest ogólnie przyjęta w badaniach architektury, podkreślają to chociażby Marian Arszyński, Organizacja i technika średniowiecznego budownictwa ceglanego $w$ Prusach $w$ kontekście europejskim (Malbork: Muzeum Zamkowe, 2016), 5-10; Marian Arszyński, „Kilka uwag na temat przydatności źródeł pisanych dla procesu badań architektonicznych domów mieszczańskich w Toruniu”, w Badania architektoniczne. Historia i perspektywy rozwoju, red. Marian Arszyński et al. (Toruń: Wydział Sztuk Pięknych UMK, 2015), 215-226; Jan Tajchman i Joanna Kucharzewska, „Znaczenie wyników badań historyczno-architektonicznych dla projektów i realizacji konserwatorskich (na przykładzie wybranych zabytków Torunia)”, w Badania architektoniczne, 413.

4 Arszyński, Organizacja, 9. 
amunicyjny), a jako ostatnia tzw. Mała Zbrojownia z lat 1643-16455. Analiza bogatych źródeł dostarcza szczegółowych informacji na temat tych inwestycji, a także organizacji procesu budowlanego w nowożytnym Gdańsku. Co równie ważne, każe ona zakwestionować niektóre z ugruntowanych w literaturze opinii, zwłaszcza dotyczących osób biorących udział w procesie powstawania tych obiektów.

\section{Spichrz Królewski}

Spichrz Królewski został wzniesiony w latach 1606-1608 na Ołowiance ${ }^{6}$. Gdańsk został zobowiązany do utrzymania magazynu dla potrzeb króla już w porozumieniu zawartym z Kazimierzem Jagiellończykiem w czasie wojny trzynastoletniej ${ }^{7}$.Zanim na początku XVII wieku stanął znany dziś budynek, zboża i pozostałe dobra będące własnością króla magazynowano w innych miejscach. Wskazują na to słowa Stefana Batorego, który w 1582 roku nakazał remont spichrza wybudowanego „przed wielu laty”, oraz polecenie wydane w 1595 roku przez Zygmunta III królewskiemu faktorowi w Gdańsku Szymonowi Bahrowi, by wyszukał dla niego odpowiedni magazyn ${ }^{8}$.

Wzniesiony na początku XVII wieku spichrz związany był z ekonomią malborską, kluczami doń dysponowali kolejni królewscy faktorzy w Gdańsku,

5 Punktem wyjścia do tych rozważań była kwerenda przeprowadzona na potrzeby Atlasu Architektury Gdańska, poszerzona i uzupełniona na potrzeby niniejszego artykułu.

6 O tym budynku m.in. Cuny, Danzigs Kunst, 56; Tadeusz Kruszyński, Stary Gdańsk i historya jego sztuki (Kraków: nakł. Księgarni Wydawniczej J. Czerneckiego w Wieliczce, 1912), 99, 106; Paul Simson, Geschichte der Stadt Danzig, t. 2 Von 1517 bis 1626 (Danzig: A. W. Kafemann, 1918), 247, 560; I.[ngmar] Koska, „Strakofski (Strackowitz, Strackwitz), Hans”, w Allgemeines Lexikon der Bildenden Künstler von der Antike bis zu Gegenwart, red. Ulrich Thieme i Felix Becker, t. 32 (Lepizig: E. A. Seemann, 1938), 152; Jerzy Stankiewicz, Strakowscy. Fortyfikatorzy, architekci i budowniczowie gdańscy (Gdańsk: Ossolineum 1955), 35-36, 52-55, 91; Andrzej Januszajtis, „Z dziejów Ołowianki”, Zeszyty Naukowe Politechniki Gdańskiej. Architektura 20 (1981): 185-92; Helena Sikorska, „Spichrz królewski”, Zeszyty Naukowe Politechniki Gdańskiej. Architektura 10 (1970): 141-42; Friedrich, Gdańskie zabytki, 220-221; Jadwiga Habela, „Strakowski (Strakoffsky, Strackowitz, Strakwitz) Jan (Hans) (ok. 1567-1642)”, w Słownik biograficzny Pomorza Nadwiślańskiego, t. 4 (Gdańsk: TPNiS, 1997), 277-278; Arnold Bartetzky, Das Grosse Zeughaus in Danzig. Baugeschichte. Architekturgeschichtliche Stellung. Repräsentative Funktion (Stuttgart: Franz Steiner, 2000), 158.

7 Henryk Samsonowicz, „Gdańsk w okresie wojny trzynastoletniej”, w Historia Gdańska, t. 2 1454-1655, red. Edmund Cieślak (Gdańsk: Wydawnictwo Morskie, 1982), 73.

8 Archiwum Państwowe w Gdańsku (dalej: APG), 300, 53/33, nr 4; APG, 300, 53/42; też Januszajtis, „Z dziejów”, 187-88. 
a koszty utrzymania ponosiło miasto ${ }^{9}$. Budowa, finansowana z kasy miasta, ruszyła w roku 1606 (rozpoczęto ją najprawdopodobniej w sierpniu), ukończona zaś została w październiku 1608 roku $^{10}$. Zgodnie z ówczesną praktyką prace prowadzili reprezentanci różnych zawodów. Abraham van den Blocke, mistrz cechu murarzy, kamieniarzy i rzeźbiarzy, regularnie zatrudniany przez władze miasta do wykonania robót kamieniarskich i rzeźbiarskich, odpowiadał za elementy kamieniarskie ${ }^{11}$. Hans von Jülich, pełniący w tym czasie funkcję miejskiego cieśli (Stadtzimmermann), kierował pracami ciesielskimi. Ponieważ wewnętrzna struktura budynku (stropy z podporami, schody, winda towarowa) była wykonana $\mathrm{z}$ drewna, miały one zapewne duży zakres. Na rzecz inwestycji działał też kowal Andreas Stange - rzemieślnicy tego zawodu niemal zawsze brali udział w pracach budowlanych, zarówno bezpośrednio, jak i pośrednio, dostarczając narzędzi i materiałów ${ }^{12}$. W przedsięwzięciu uczestniczył wreszcie Bauknecht Philip Schumacher, ze względu na charakter swego urzędu zaangażowany w budowę wielu obiektów finansowanych z kasy miasta. Schumacher nadzorował robotników, pomocników i pracowników dniówkowych zatrudnionych przy publicznych realizacjach budowlanych, którzy zajmowali się szeroko pojętą obsługą placu budowy, dostarczając materiały i wykonując inne proste czynności ${ }^{13}$.

Źródła milczą natomiast o zaangażowaniu w budowę Hansa Strakowskiego. Teza o jego udziale w budowie spichrza została wysunięta przez Georga Cuny'ego, a następnie utrwalona w polskiej literaturze przez Jerzego Stankiewicza ${ }^{14}$. W odróżnieniu od paru innych supozycji Cuny'ego, miał on ku temu pewne podstawy źródłowe. Według niego w suplice skierowanej do władz miasta w 1635 roku - znanej dziś jedynie za pośrednictwem jego książki Strakowski miał wymienić „spichrz królewski” wśród obiektów, przy których

9 W liście królewskim z 1627 r. pisano o spichrzu: ad Oeconomiam Mariaburgensis pertinentis, zob. APG, 300, 53/49, nr 5.

10 APG, 300, 12/34, 154; APG, 300, 12/36, 28. Datowanie takie jako pierwsza wskazała Sikorska, „Spichrz”, 141.

11 Sikorska, „Spichrz”, 141. O jego innych pracach - choć to zapewne niekompletny katalog zob. Franciszek Skibiński, „Warsztat Abrahama van den Blocke i publiczne przedsięwzięcia budowlane w Gdańsku w pierwszej ćwierci XVII wieku”, Biuletyn Historii Sztuki 77 (2015): 241-65.

12 Por. np. Arszyński, Organizacja, 135-38.

13 O nim już Franciszek Skibiński, „Kilka uwag o Hansie Strakowskim, Simonie Herle i architekturze gdańskiej przełomu XVI i XVII w.”, Porta Aurea. Rocznik Instytutu Historii Sztuki Uniwersytetu Gdańskiego 11 (2012): 127, oraz Skibiński, „Warsztat”, 256-57.

14 Cuny, Danzigs Kunst, 56; Stankiewicz, Strakowscy, 91; patrz też Sikorska, „Spichrz”, 141. 
pracował. O problemach związanych z interpretacją treści tej supliki pisałem już w innym miejscu ${ }^{15}$. Jest jednak możliwe, a nawet prawdopodobne, że Strakowski istotnie pracował przy spichrzu, lecz nie przy jego budowie - co raczej wykluczają znane źródła - ale przy którejś z napraw lub przebudów ${ }^{16}$.

Prawdopodobieństwo tej interpretacji uzasadnia wykonywanie częstych remontów bądź modyfikacji w trakcie użytkowania budynków. Dowodzą tego dobrze udokumentowane przykłady takich działań, zarówno w Gdańsku, jak i w innych miastach Rzeczpospolitej. Praktykę tę ilustrują chociażby zakrojone na większą lub mniejszą skalę prace naprawcze prowadzone niemal każdego roku w gdańskim ratuszu. Strakowski był przez wiele lat zatrudniany przez władze miasta do realizacji bardzo różnych przedsięwzięć, od wznoszenia nowych budynków, przez poważne przebudowy, jak w przypadku Dworu Artusa, po mniejsze przekształcenia istniejących obiektów. Roboty takie mogły wykonywać równolegle w kilku miejscach ekipy czeladników nadzorowane przez mistrza ${ }^{17}$.

Spichrz poddano poważniejszym naprawom już w 1621 roku. Wiadomo o tym z listu władz Gdańska do ekonoma malborskiego Melchiora Wejhera ${ }^{18}$. Rachunki miejskie wskazują, że Strakowski był w tym czasie zaangażowany w różne czynności na rzecz miasta. Na przykład, w roku rachunkowym 1622-1623 odnotowano jego nazwisko w dziale kamlarii określanym jako Stadgebaude, nie podając jednak szczegółów ${ }^{19}$. W tym samym roku kierowani przezeń murarze pracowali też przy Neuen Thor ${ }^{20}$. Natomiast rok wcześniej zanotowano, że działał między innymi przy obiektach określonych jako Pulwermuhl (młyn prochowy) i Wachthaus (dom straży) ${ }^{21}$. Nie można więc wykluczyć - choć w trakcie dotychczasowej kwerendy nie znaleziono zapisu mówiącego o tym wprost - że przeprowadził on również wspomniany w liście do Wejhera remont spichrza.

Pisząc o wczesnej historii spichrza warto dodać, że budowa nowego magazynu nie zakończyła problemów z przechowywaniem zboża i innych dóbr należących do króla. Już w kwietniu 1613 roku Zygmunt III zwrócił się do

\footnotetext{
Skibiński, „Kilka uwag”, 127-28.

6 Sikorska, „Spichrz”, 141.

17 Świadczy o tym między innymi publikowany już kwit tygodniowy z 1616 roku, patrz: APG, 300, 12/298, 71; Skibiński, „Warsztat”, 255-56.

18 APG, 300, 27/55, 303-6; Simson, Geschichte, 560, przyp. 6; Sikorska, „Spichrz”, 141.

19 APG, 300, 12/53, 106.

20 APG, 300, 12/53, 114.

21 APG, 300, 12/52, 15.
} 
gdańskiej rady w sprawie bezprawnego zajęcia należącego doń spichrza, powołując się na informacje pochodzące od Ludwika Wejhera, podskarbiego ziem pruskich i ekonoma malborskiego, w którego gestii budynek się znajdował ${ }^{22}$. Interesującym epizodem w historii spichrza jest też okres tzw. wojny o ujście Wisły w latach 1626-1629. W tym czasie obiekt ten służył jako królewska zbrojownia, o czym pisał w liście do gdańskiej rady z 1627 roku sam Zygmunt III, nakazując opróżnić część budynku w celu magazynowania tam uzbrojenia ${ }^{23}$. Jednocześnie monarcha polecił radzie, by wyznaczyła odpowiednie miejsce na towary rozładowywane z królewskich statków. Jeszcze w 1633 roku spichrz był zajęty przez sprzęt wojenny, wobec czego król Władysław IV kazał władzom miasta znaleźć inny magazyn na zboże z majątków swej małoletniej siostry Anny Katarzyny ${ }^{24}$. Z przekazem tym połączyć można informację, że w 1637 roku uzbrojenie królewskiej artylerii przeniesiono z Gdańska do arsenału koronnego znajdującego się w obrębie zamku malborskiego (Karwan) ${ }^{25}$. W dużej partii sprzętu wojennego było między innymi dwadzieścia sześć dział. Zestawiając te fakty można podejrzewać, że część tego sprzętu wcześniej przechowywano właśnie w spichrzu, który tym samym do około 1637 roku pełnił funkcję królewskiego arsenału w Gdańsku, a szerzej - w Prusach. Było to zresztą logiczne z punktu widzenia taktyki wojennej, nad Motławą bowiem cenne armaty i inny sprzęt były dobrze zabezpieczone przed niespodziewanym zagarnięciem przez Szwedów, w latach 1626-1635 zajmujących niedaleki Elbląg i działających w całych Prusach.

\section{Tak zwana Mała (Nowa) Zbrojownia}

Najmłodsza z omawianych tu budowli jest tzw. Mała Zbrojownia, w źródłach z czasów budowy nazywana „Nową Zbrojownią” (Neue Zeughaus) ${ }^{26}$. O ile

22 APG, 300, 53/46, nr 26.

23 APG, 300, 53/49, nr 5.

24 APG, 300, 53/67, nr 11.

25 Tadeusz M. Nowak, Polska technika wojenna XVI-XVII wieku (Oświęcim: Napoleon V, 2016), 189.

26 O tym budynku m.in. Matthias Gotthilf Löschin, Geschichte Danzigs von der ältesten bis zur neuesten Zeit, t. 1 (Danzig: F. W. Ewert, 1822), 352; Matthias Gotthilf Löschin, Danzig und Seine Umgebungen (Danzig: im Verlage der S. Anhuthschen Buchhandlung, 1836), 63; Wilhelm Ferdinand Zernecke, Neuster Wegweiser durch Danzig und dessen Umgegend (Danzig: Verlag Fr. Sam. Gerhard, 1843), 301; Karl Hoburg, Geschichte der Festungswerke Danzigs (Danzig: Wedelsche Hofbuchdruckerei, 1852), 65; Gustav Köhler, Geschichte der Festungen Danzig und Weichselmünde bis zum Jahre 1814 in Verbindung mit der Kriegsgeschichte der freien Stadt Danzig, t. 1 Bis zum Jahre 1734 (Breslau: Verlag von Wilhelm Koebner, 1893), 331; Cuny, Danzigs 
spichrz pełnił funkcję arsenału dość przypadkowo, o tyle zbrojownia była od początku pomyślana jako magazyn sprzętu wojennego, co odzwierciedla jej wysoce indywidualny układ przestrzenno-funkcjonalny i co za tym idzie - forma architektoniczna. Powstała ona w latach czterdziestych XVII wieku na południowo-zachodnim krańcu niedawno rozbudowanych obwarowań miejskich, między tzw. Bastionem Wijbego (nazwa odnosząca się do czynnego w ówczesnym Gdańsku „budowniczego wodnego” Adama Wiebe) a Bastionem św. Gertrudy. Budowę rozpoczęto we wrześniu 1643 roku, ukończono zaś w roku 1645 - data „1645” znalazła się w kartuszu umieszczonym na fasadzie budynku - choć prace wykończeniowe mogły trwać jeszcze do początku kolejnego roku ${ }^{27}$. Podobnie jak przy wznoszeniu Królewskiego Spichrza, w budowie zbrojowni brało udział kilku specjalistów, reprezentujących różne zawody. Roboty murarskie prowadził warsztat kierowany przez Reinholda de Clerck (Deklercke) ${ }^{28}$. Był to, regularnie zatrudniany przez władze Gdańska, mistrz tamtejszego cechu murarzy, kamieniarzy i rzeźbiarzy, być może spokrewniony z czynnym nad Motławą w pierwszej ćwierci XVII wieku Franzem de Clerck. Już w 1629 roku pracował dla miasta, dokonując naprawy mieszkania kaznodziei w Wisłoujściu, a w latach 1632-1633 systematycznie otrzymywał wynagrodzenie wykazane w dziale Stadgebaude, obok miejskiego cieśli Jakuba van den Blocke i Bauknechta Philipa Schumachera ${ }^{29}$. Warto dodać, że de Clerck razem z Wilhelmem Richterem stawiał Długim Targu elementy fontanny Neptuna wykonane z kamienia przez Abrahama van den Blocke, za co w lutym 1633 roku otrzymał 450 grzywien $^{30}$. Robotami ciesielskimi prowadzonymi w Małej Zbrojowni kierował Hans Schumacher, pełniący w tym czasie bardzo ważną dla gdańskiego budownictwa funkcję cieśli miej-

Kunst, 58; Kruszyński, Stary Gdańsk, 108; Otto Kloeppel, Das Stadtbild von Danzig in den drei Jahrhunderten seiner großen Geschichte (Danzig: A.W. Kafemann, 1937), 110; Stankiewicz, Strakowscy, 76-80; Keyser, Die Baugeschichte, 372; Friedrich, Gdańskie zabytki, 70-72; Habela, „Strakowski”, 278-79; Bartetzky, Das Große Zeughaus, 20; Bogusław Dybaś, „Strakowski (von Strackwitz, Strakofski, Strakowitz) Jerzy (Georg, Georgius)", in Polski słownik biograficzny, t. 44/2, z. 181 (Warszawa: PAU/Ossolineum, 2006), 178.

27 APG , 300,12/81, 167-69. Rachunki za prace przy Nowej Zbrojowni kończą się w lutym $1646 \mathrm{r}$.

28 APG, 300, 12/77, s. 59, 63, 75, 97; jego udziału nie odnotowano w 1645 r. (APG, 300, 12/81), choć otrzymywał w tym czasie wypłaty w ramach Stadtgebaude (APG, 300, 12/81, s. 43).

29 APG, 300, 12/59, 127; APG, 300, 12/64, 106-13.

30 APG, 300, 12/63, 247; APG, 300, 12/64, 115 . O jej historii zob. Helmut Carl, „Der Neptunbrunnen auf dem Langen Markte zu Danzig. Seine Entstehung und Geschichte”, Zeitschrift für Kunstgeschichte 6 (1937): 148, 162-63; Lars Olof Larsson, „Studnia Neptuna w Gdańsku“, Porta Aurea 10 (2011): 5-23. Trzeba jednak podkreślić, że nie wszystkie podane tam informacje są poprawne, zob. Skibiński, „Warsztat”. 
skiego ${ }^{31}$. Poza tym w prace zaangażowanych było kilku rzemieślników innych zawodów, między innymi kowal Josua Mundt ${ }^{32}$.

W literaturze przedmiotu utrwaliła się opinia, jakoby budowniczym Małej Zbrojowni był Jerzy (Georg) Strakowski. Trzeba więc zauważyć, że nie wspomnieli o tym piszący o budynku dziewiętnastowieczni autorzy - Matthias Gotthilf Löschin, Wilhelm Ferdinand Zernecke, Karl Hoburg i Gustav Köhler $^{33}$. Tezę o udziale Strakowskiego wysunął dopiero Georg Cuny ${ }^{34}$, przy czym nie przytoczył żadnych argumentów na jej poparcie, przywołał jedynie publikację Gustava Köhlera, gdzie takiej informacji nie ma ${ }^{35}$. W polskiej historiografii teza ta została utrwalona przez Jerzego Stankiewicza ${ }^{36}$. Co wszakże znamienne, Stankiewicz nie wskazał na żadne źródła ani nawet na literaturę - choć pogląd zapożyczył od Cuny’ego - a jedyny odnośnik kieruje czytelnika do dzieła Reinholda Curickego; w dodatku powołał się na tego autora nie w kwestii autorstwa, o czym Curicke milczy, lecz datowania prac budowlanych ${ }^{37}$. Niemniej jednak autorytet Cuny'ego i Stankiewicza sprawił, że niezweryfikowana teza o autorstwie Jerzego Strakowskiego była wielokrotnie powtarzana, zarówno w opracowaniach o charakterze naukowym, jak i w różnego typu publikacjach popularyzujących wiedzę o dziejach Gdańska. Tymczasem trzeba podkreślić, że w dobrze zachowanych rachunkach budowlanych brak jakichkolwiek wzmianek o tym budowniczym. Co więcej, w czasie budowy zbrojowni Strakowski był zaangażowany w inne prace, m.in. przy Nechrungschegebaude, a więc na Mierzei Wiślanej38.

Do dekoracji elewacji w ograniczonym zakresie użyto detalu rzeźbiarskiego wykonanego z kamienia. W łukach bram umieszczono zworniki z płaskorzeźbionymi ozdobnymi panopliami i stylizowanymi przedstawieniami moździerzy. Najbardziej okazałym elementem dekoracji jest zachowany do dziś, wykonany z piaskowca i pierwotnie zapewne polichromowany kartusz. Składa

31 APG, 300, 12/77, 61 (tu też za prace w Altzeughaus, a więc Wielkiej Zbrojowni), 81; APG, 300, 12/81, 167-69.

32 APG, 300, 12/77, 77; APG, 300, 12/81, 167.

33 Löschin, Geschichte Danzigs, 352; Löschin, Danzig, 63; Zernecke, Neuster Wegweiser, 301; Hoburg, Geschichte, 65; Köhler, Geschichte, 331.

34 Cuny, Danzigs Kunst, 58.

35 Köhler, Geschichte, 331.

36 Stankiewicz, Strakowscy, 75-6.

37 Reinhold Curicke, Der Stadt Danzig Historische Beschreibung (Amsterdam, Danzig: Johann und Gillis Janssons von Waesberge, 1687), 58.

38 APG, 300, 12/81, 81; wypłaty dlań odnotowane w maju, sierpniu i październiku 1645 r. O znaczeniu tego określenia zob. np. APG, 300, 12/72, 85. 
się on z centralnej tablicy z herbem Gdańska oraz fartucha i zwieńczenia, wydzielonych gzymsami, z których górny złożony jest z płyty i simy. Część centralna ma formę kwadratowej, profilowanej ramy z prostokątnie wyłamanymi narożami, ujętej niewielkimi, małżowinowymi uszakami. W centrum tablicy umieszczono rzeźbiony herb Gdańska z trzymaczami w postaci lwów, natomiast pośrodku małżowinowego kartusza w dolnej partii znalazła się prostokątna płycina z datą „1645”. Zwieńczenie ma kształt przerwanego, wklęsło-wypukłego naczółka, o gzymsie przechodzącym w centrum w małżowinę.

Tablica herbowa, przypominająca szereg innych dzieł ówczesnej kamieniarki gdańskiej, na przykład dekorację szczytów kamienic przy ul. Targ Rybny 6 z lat 1652 i 1654 (co samo w sobie oczywiście nie przesądza o ich autorstwie), oraz pozostałe elementy dekoracji rzeźbiarskiej powstały w warsztacie Wilhelma Richtera, odpowiedzialnego za wykonanie kamieniarki Małej Zbrojowni ${ }^{39}$. Za prace kamieniarskie przy tej budowli 26 sierpnia 1645 roku wypłacono mu pozostałe 597 grzywien z ogólnej sumy 2670 grzywien ${ }^{40}$. Jeszcze jednak w październiku otrzymał dodatkowo wynagrodzenie za „haackstein”, w grudniu zaś za „ein stuck stein” ${ }^{41}$. Można dodać, że jego nazwisko pojawia się w tym czasie też w dokumentach działu Stadtgebaude ${ }^{42}$.

Richter należał w tym czasie do czołowych gdańskich rzeźbiarzy i kamieniarzy. Był spadkobiercą słynnej gdańskiej pracowni rzeźbiarskiej, kierowanej kolejno przez Willema i Abrahama van den Blocke, i pracował dla zleceniodawców zarówno z Gdańska, jak i z głębi Rzeczpospolitej, między innymi dla arcybiskupa gnieźnieńskiego Macieja Łubieńskiego ${ }^{43}$. W omawianym okresie często angażowały go władze Gdańska, realizował dla nich prace różnego typu. Warto przybliżyć to zagadnienie, nie zostało ono bowiem dostatecznie wyjaśnione w literaturze. Być może jako pierwsze zamówienie rady Richter ustawiał, a być może też uzupełniał i poprawiał elementy fontanny Neptuna, za co otrzymał wynagrodzenie w lutym i marcu $1633 \mathrm{roku}^{44}$. Określony jako rzeźbiarz i kamieniarz, był już wtedy osobą szanowaną za wiedzę i sztukę ${ }^{45}$.

\footnotetext{
39 APG, 300, 12/77, 59, 75, 97, 99 (wypłaty z 1643 i 1644 r.); APG, 300, 12/81, 167-68.

40 APG, 300, 12/81, 168.

$41 \quad$ APG, 300, 12/81, 168-69.

42 APG, 300, 12/81, 44-56.

43 Maria Heydel, „Richter Wilhelm”, w Słownik artystów polskich i obcych w Polsce działających (zmarłych przed 1966 r.), t. 8, red. Urszula Makowska i Katarzyna Mikocka-Rachubowa (Warszawa: Instytut Sztuki PAN, 2007), 349-51.

44 APG, 300, 12/63, 259, 269, 281; APG, 300, 12/64, 115.

45 APG, 300, 12/63, 259; zapis z 19 lutego 1633 r.
} 
W ciągu roku rachunkowego 1637/1638 Richter brał udział w zakrojonych na dużą skalę, kosztownych pracach przy kompleksie Bramy Wyżynnej ${ }^{46}$. Oprócz niego działali tam Reinhold de Clerck i Hans Schumacher, a także specjalista od budownictwa i inżynierii wodnej Adam Wiebe. W tym samym czasie Richter był również zaangażowany w Wisłoujściu ${ }^{47}$. Roboty przy kompleksie Bramy Wyżynnej kontynuowano w roku 1638/163948. Richter otrzymał wynagrodzenie za dostarczenie dwóch partii kamienia gotlandzkiego (we wrześniu 1000 stóp, w listopadzie 1011 stóp), który następnie opracowywał ${ }^{49}$. Przekaz ten sugeruje, że Richter - podobnie jak wcześniej Willem van der Meer Młodszy - zajmował się także sprowadzaniem materiałów kamieniarskich z wysp bałtyckich $^{50}$.

Przez kilka lat Richter działał też w ratuszu Głównego Miasta. Już w roku 1640/1641 uczestniczył w pracach przy portalu i schodach tego budynku ${ }^{51}$. Realizował je wraz z innymi przywoływanymi tu rzemieślnikami, przede wszystkim mistrzem murarskim Reinholdem de Clerck, cieślą miejskim Hansem Schumacherem i kowalem Josuą Mundtem. Warto dodać, że specjalnie na potrzeby tych zamówień zakupiono od Christiana Willemsena sporą ilość „gottlandishe blocksteine”. Prace przy portalu Richter kontynuował w latach $1642 \mathrm{i} 1643^{52}$. W tym czasie był regularnie zatrudniany przez miasto ${ }^{53}$. Jego zaangażowanie w ratuszu odnotowano jeszcze w 1645 roku. W czerwcu tego roku wykonał fragmenty detalu kamieniarskiego ${ }^{54}$, jesienią zaś elementy portalu, w tym miecz dla figury Iustitii oraz inskrypcję, złoconą następnie przez malarza Adolfa Boya ${ }^{55}$.

\section{Tak zwana Stara Apteka}

Zanim podjęto decyzję o budowie drugiego arsenału, w latach trzydziestych rozbudowano kompleks Wielkiej Zbrojowni. W tym czasie wzniesiono na-

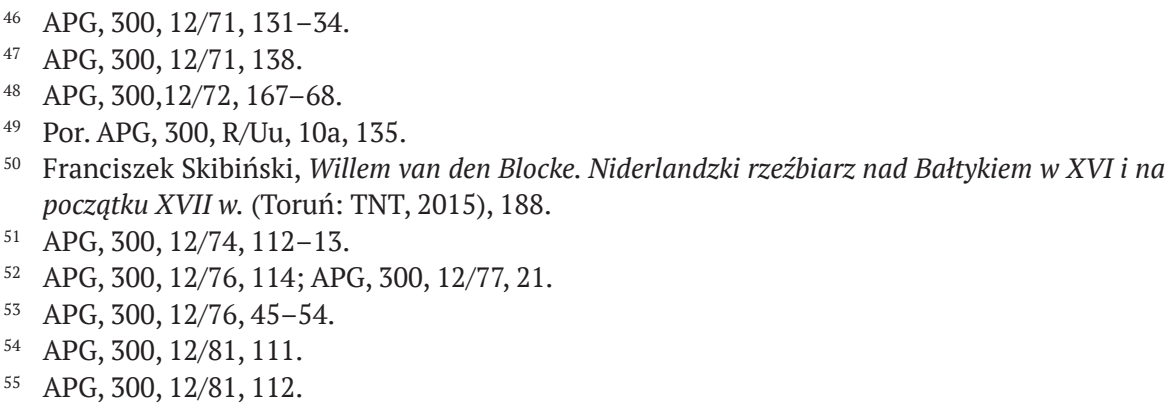


leżącą doń tzw. Starą Aptekę ${ }^{56}$. Według ryciny zamieszczonej w dziele Curickego, budynek ten był oddzielony od zbrojowni obszernym dziedzińcem, ograniczonym od zachodu murem z półkoliście zamkniętą bramą wjazdową i dekoracyjnie opracowanymi półszczytami ${ }^{57}$. Curicke pisał, że wzniesiona na początku XVII wieku Wielka Zbrojownia nie mogła pomieścić całego zgromadzonego uzbrojenia, wobec czego zdecydowano się na jej rozbudowę $e^{58}$. Autor marginaliów do tego dzieła dodaje, że strażnicy (Zeugwärter) nazywali nowy budynek apteką (Apotheke) z powodu nagromadzenia w nim kartaczy, kul i granatów $\mathrm{w}^{59}$. Pełnił on więc prawdopodobnie funkcję magazynu amunicyjnego.

Prace przy nim rozpoczęto w maju 1636 roku. W maju i czerwcu dokonano wypłat wynagrodzenia dla znanego nam już mistrza budowlanego Reinholda de Clerck za wyburzenie starej zabudowy przy Wielkiej Zbrojowni ${ }^{60}$. Zaraz potem przystąpiono do stawiania nowego obiektu, określanego w źródłach - podobnie jak w przypadku tzw. Małej Zbrojowni - jako „nowa zbrojownia” (Neuzeughaus) lub po prostu Zeughausgebaude. Prace wykonywali w znacznej części ci sami budowniczowie, którzy będą później zatrudnieni przy Małej Zbrojowni. Robotami murarskimi kierował Reinhold de Clerck, wymieniany w rachunkach niemal przez cały okres budowy ${ }^{61}$, ciesielskimi zaś Hans Schumacher ${ }^{62}$. Kamieniarkę wykonał Herman Knut (Knust), mistrz gdańskiego cechu murarzy, kamieniarzy i rzeźbiarzy ${ }^{63}$. Knut został odnotowany w rachunkach budowy już w lipcu 1636 roku, kiedy otrzymał wynagrodzenie za prace kamieniarskie przy nowym obiekcie ${ }^{64}$. Można mu chyba na tej podstawie przypisać elementy kamieniarskiego wystroju fasady, w tym portal. Knut pracował dla miasta też przy innych okazjach. W roku 1637/1638 otrzymał zapłatę za wykonanie (i położenie) flizów w Dworze Artusa oraz za roboty

56 O tym budynku m.in. Hoburg, Geschichte, 35; Gustav Bädeker, Chronologische Notizen aus der Baugeschichte der wesentlichsten Danziger Bauwerke (Danzig: Ernst Gruihn's Verlag, 1879), 29; Ernst Blech, Danzig als Kunststätte (Danzig: Verlag von L. Saunnier's Buchhandlung, 1904), 50-51; Kruszyński, Stary Gdańsk, 103-4; Kloeppel, Das Stadtbild, 110; Friedrich, Gdańskie zabytki, 70; Bartetzky, Das Große Zeughaus, 20, 23, 33, 54, 195-96.

57 Curicke, Der Stadt Danzig, 58.

58 Curicke, Der Stadt Danzig, 59.

59 Curicke, Der Stadt Danzig, 59.

60 APG, 300, 12/69, 157.

61 APG, 300, 12/69, 157-58; APG, 300, 12/71, 171-72.

62 APG, 300, 12/69, 157-58; APG, 300, 12/71, 171-73.

63 APG, 300, 12/69, 157-58; APG, 300, 12/71, 172.

64 APG, 300, 12/69, 157; APG, 300, 12/71, 173. 
w ratuszu ${ }^{65}$. W rachunkach miejskich został wymieniony już w 1633 roku, dostarczył wtedy kamienne elementy do Wisłoujścia ${ }^{66}$. Oprócz nich zostali zatrudnieni też inni rzemieślnicy, w tym znany już nam kowal Josua Mundt, wielokrotnie pracujący na rzecz miasta, oraz Zacharias Pfeffern i Heinrich Kramer ${ }^{67}$.

W roku 1636 prace budowlane trwały do października, a rozpoczęto je ponownie w kwietniu następnego roku $^{68}$. Uczestniczyli w nich ci sami rzemieślnicy, poza kamieniarzem Knutem, który swoją część prac wykonał już w trakcie poprzedniego sezonu budowlanego. Wydaje się, że stosunkowo proste elementy wystroju kamieniarskiego elewacji obiektu mogły być - w odróżnieniu na przykład od szczytów Wielkiej Zbrojowni - wykonane wcześniej i wmurowane we właściwe miejsca przez warsztat murarski ${ }^{69}$. We wrześniu 1637 roku budynek był już zadaszony, a jego szata zewnętrzna ukończona. Świadczy o tym wypłacenie 19 września niejakiemu Andresowi Hoffmanowi wynagrodzenia za pomalowanie farbą olejną szczytu (giebel) i za wyzłocenie kamiennych rzeźb lwów (Löwen $)^{70}$. Dalsze roboty miały zapewne charakter wykończeniowy i prowadzone były we wnętrzach. Zajmował się nimi głównie Schumacher, wykonując wewnętrzne, drewniane elementy budynku ${ }^{71}$. Pracowali też inni, na przykład kowal Peter Leinehl wykuł metalowe części, w tym okucia drzwi. Malarz Andreas Hoffman w czerwcu otrzymał wynagrodzenie za malowanie ołowianych rynien farbą olejną w biało-czerwone pasy, natomiast we wrześniu za malowanie między innymi obu bram i dalszych elementów kamiennych ${ }^{72}$. Prace ostatecznie zakończono wczesną jesienią 1638 roku.

\section{Podsumowanie}

Omówione tu materiały źródłowe dostarczają bogatych i szczegółowych informacji o budowie ważnych, w znacznym stopniu zachowanych do dziś obiektów pochodzących z okresu świetności Gdańska. Poszerzając wiedzę o samych budynkach, rzucają one światło na gdańskie środowisko budowlane

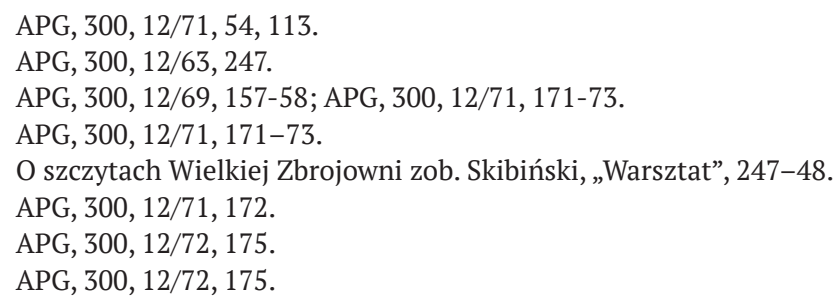


tego czasu oraz przebieg dawnych procesów budowy. Cenne są w nich zwłaszcza nowe informacje o kilku gdańskich mistrzach budowlanych, rzeźbiarzach i kamieniarzach, zarówno takich dobrze znanych, jak Wilhelm Richter, jak i takich, o których wzmianki są w literaturze bardzo skromne, jak kamieniarz Herman Knut (Knust) i mistrz budowlany Reinhold de Clerck. Zestawienie przywołanych tu źródeł, dotyczących różnych przedsięwzięć podejmowanych przez tych rzemieślników, pozwala na dość szczegółową rekonstrukcję przynajmniej fragmentu ich kariery. W szerszym kontekście informacje te uzupełniają wiedzę o działalności budowniczych w tym czasie. Trzeba bowiem pamiętać, że w procesie budowlanym uczestniczyli nie tylko murarze i kamieniarze, ale też przedstawiciele innych zawodów, w tym cieśle, kowale, ślusarze, szklarze, malarze i inni. Niektórzy z nich pracowali bezpośrednio na placu budowy, inni dostarczali materiały i narzędzia, wszyscy byli jednak niezbędnymi ogniwami procesu powstawania budynku. Analiza źródeł potwierdza przy tym wysuniętą już wcześniej tezę, że osoby regularnie angażowane do miejskich prac budowlanych tworzyły stałą i stosunkowo niewielką grupę rzemieślników. W mieście, w którym działało wielu murarzy i kamieniarzy, a także kowali i innych rzemieślników, w rachunkach budowlanych z lat trzydziestych i czterdziestych XVII wieku - podobnie zresztą jak na początku stulecia - pojawiają się cały czas te same nazwiska. Pewne informacje zawarte w aktach, takie jak na przykład dotycząca pierwotnej kolorystyki rynien tzw. Starej Apteki, mogą mieć wreszcie znaczenie dla prowadzonych w nich współcześnie prac konserwatorskich i restauratorskich.

\section{Bibliografia}

\section{Materiały archiwalne}

Archiwum Państwowe w Gdańsku, Akta Miasta Gdańska, Kamlaria (1377-1814/1894), sygn. 300, 12/34; 300, 12/36; 300, 12/52; 300, 12/53; 300, 12/59; 300, 12/63; 300, $12 / 64 ; 300,12 / 69 ; 300,12 / 71 ; 300,12 / 72 ; 300,12 / 74 ; 300,12 / 76 ; 300,12 / 77 ; 300$, $12 / 81 ; 300,12 / 298$.

Archiwum Państwowe w Gdańsku, Akta Miasta Gdańska, Missiva (1420-1793, 1807-1810), sygn. 300, 27/55.

Archiwum Państwowe w Gdańsku, Akta Miasta Gdańska, Listy i dokumenty (1525-), sygn. 300, 53/33; 300, 53/42; 300, 53/46; 300, 53/49; 300, 53/67.

Archiwum Państwowe w Gdańsku, Akta Miasta Gdańska, „Bibliotheca Archivi”, sygn. 300, R/Uu 10a. 


\section{Druki i opracowania}

Arszyński, Marian. „Kilka uwag na temat przydatności źródeł pisanych dla procesu badań architektonicznych domów mieszczańskich w Toruniu”. W Badania architektoniczne. Historia i perspektywy rozwoju, red. Marian Arszyński, Maciej Prarat, Ulrich Schaaf i Bożena Zimnowoda-Krajewska, 215-226. Toruń: Wydział Sztuk Pięknych UMK, 2015.

Arszyński, Marian. Organizacja i technika średniowiecznego budownictwa ceglanego $w$ Prusach $w$ kontekście europejskim. Malbork: Muzeum Zamkowe, 2016.

Bädeker, Gustav. Chronologische Notizen aus der Baugeschichte der wesentlichsten Danziger Bauwerke. Danzig: Ernst Gruihn's Verlag, 1879.

Bartetzky, Arnold. Das Große Zeughaus in Danzig. Baugeschichte. Architekturgeschichtliche Stellung. Repräsentative Funktion. Stuttgart: Franz Steiner, 2000.

Blech, Ernst. Danzig als Kunststätte. Danzig: Verlag von L. Saunnier’s Buchhandlung, 1904.

Carl, Helmut. „Der Neptunbrunnen auf dem Langen Markte zu Danzig. Seine Entstehung und Geschichte”. Zeitschrift für Kunstgeschichte 6 (1937): 147-70.

Cuny, Georg. Danzigs Kunst und Kultur im 16. und 17. Jahrhundert. Frankfurt am Main: Heinrich Keller Verlag, 1910.

Curicke, Reinhold. Der Stadt Danzig Historische Beschreibung. Amsterdam, Danzig: Johann und Gillis Janssons von Waesberge, 1687.

Dybaś, Bogusław. „Strakowski (von Strackwitz, Strakofski, Strakowitz) Jerzy (Georg, Georgius)". W Polski słownik biograficzny. T. 44/2, z. 181, 177-179. Warszawa: PAU/ Ossolineum, 2006.

Friedrich, Jacek. Gdańskie zabytki architektury do końca XVIII wieku. Gdańsk: Wydawnictwo UG, 1995.

Habela, Jadwiga. „Strakowski (Strakoffsky, Strackowitz, Strakwitz) Jan (Hans) (ok. 1567-1642)”. W Słownik biograficzny Pomorza Nadwiślańskiego. T. 4, 277-278. Gdańsk: TPNiS, 1997.

Heydel, Maria. „Richter Wilhelm”. W Słownik artystów polskich i obcych w Polsce działających (zmarłych przed 1966 r.). T. 8, red. Urszula Makowska i Katarzyna Mikocka-Rachubowa, 349-351. Warszawa: Instytut Sztuki PAN, 2007.

Hoburg, Karl. Geschichte der Festungswerke Danzigs. Danzig: Wedelsche Hofbuchdruckerei, 1852.

Januszajtis, Andrzej. „Z dziejów Ołowianki”. Zeszyty Naukowe Politechniki Gdańskiej. Architektura 20 (1981): 185-192.

Keyser, Erich. Die Baugeschichte der Stadt Danzig, red. Ernst Bahr. Köln: Böhlau, 1972.

Kloeppel, Otto. Das Stadtbild von Danzig in den drei Jahrhunderten seiner großen Geschichte. Danzig: A.W. Kafemann, 1937.

Köhler, Gustav. Geschichte der Festungen Danzig und Weichselmünde bis zum Jahre 1814 in Verbindung mit der Kriegsgeschichte der freien Stadt Danzig. T. 1 Bis zum Jahre 1734. Breslau: Verlag von Wilhelm Koebner, 1893. 
Koska, I.[ngmar]. „Strakofski (Strackowitz, Strackwitz), Hans”. W Allgemeines Lexikon der Bildenden Künstler von der Antike bis zu Gegenwart, red. Ulrich Thieme i Felix Becker. T. 32, 152. Lepizig: E. A. Seemann, 1938.

Kruszyński, Tadeusz. Stary Gdańsk i historya jego sztuki. Kraków: nakł. Księgarni Wydawniczej J. Czerneckiego w Wieliczce, 1912.

Larsson, Lars Olof. „Studnia Neptuna w Gdańsku“, Porta Aurea 10 (2011): 5-23.

Löschin, Matthias Gotthilf. Danzig und Seine Umgebungen. Danzig: im Verlage der S. Anhuthschen Buchhandlung, 1836.

Löschin, Matthias Gotthilf. Geschichte Danzigs von der ältesten bis zur neuesten Zeit. Danzig: F. W. Ewert, 1822.

Nowak, Tadeusz M. Polska technika wojenna XVI-XVII wieku. Oświęcim: Napoleon V, 2016.

Samsonowicz, Henryk. „Gdańsk w okresie wojny trzynastoletniej”. W Historia Gdańska. T. 2 1454-1655, red. Edmund Cieślak, 43-76. Gdańsk: Wydawnictwo Morskie, 1982.

Sikorska, Helena. „Spichrz królewski”. Zeszyty Naukowe Politechniki Gdańskiej. Architektura 10 (1970): 141-142.

Simson, Paul. Geschichte der Stadt Danzig. T. 2 Von 1517 bis 1626. Danzig: A. W. Kafemann, 1918.

Skibiński, Franciszek. „Architekci, budowniczowie, kamieniarze i rzeźbiarze obcego pochodzenia w Gdańsku 1550-1630. Szkic z dziejów migracji artystycznej”. Biuletyn Historii Sztuki 77 (2015): 5-35.

Skibiński, Franciszek. „Kilka uwag o Hansie Strakowskim, Simonie Herle i architekturze gdańskiej przełomu XVI i XVII w.”. Porta Aurea. Rocznik Instytutu Historii Sztuki Uniwersytetu Gdańskiego 11 (2012): 123-135.

Skibiński, Franciszek. „Warsztat Abrahama van den Blocke i publiczne przedsięwzięcia budowlane w Gdańsku w pierwszej ćwierci XVII wieku”. Biuletyn Historii Sztuki 77 (2015): 241-265.

Skibiński, Franciszek. Willem van den Blocke. Niderlandzki rzeźbiarz nad Bałtykiem w XVI i na początku XVII w. Toruń: TNT, 2015.

Stankiewicz, Jerzy. Strakowscy. Fortyfikatorzy, architekci i budowniczowie gdańscy. Gdańsk: Ossolineum, 1955.

Tajchman, Jan, i Joanna Kucharzewska. „Znaczenie wyników badań historyczno-architektonicznych dla projektów i realizacji konserwatorskich (na przykładzie wybranych zabytków Torunia)”. W Badania architektoniczne. Historia i perspektywy rozwoju, red. Marian Arszyński, Maciej Prarat, Ulrich Schaaf i Bożena Zimnowoda-Krajewska, 413-440. Toruń: Wydział Sztuk Pięknych UMK, 2015.

Zernecke, Wilhelm Ferdinand. Neuster Wegweiser durch Danzig und dessen Umgegend. Danzig: Verlag Fr. Sam. Gerhard, 1843. 